Article

\title{
From Talloires to Turin: A Critical Discourse Analysis of Declarations for Sustainability in Higher Education
}

\section{Paul Sylvestre ${ }^{1, *}$, Rebecca McNeil ${ }^{1}$ and Tarah Wright ${ }^{2}$}

1 School for Resource and Environmental Studies, Dalhousie University, Halifax, Nova Scotia, B3H 4R2, Canada; E-Mail: rebecca.mcneil@dal.ca

2 Environmental Programs, Dalhousie University, Halifax, Nova Scotia, B3H 4R2, Canada; E-Mail: tarah.wright@dal.ca

* Author to whom correspondence should be addressed; E-Mail: p.a.sylvestre@dal.ca; Tel.: +1-250-505-6982; Fax: +1-902-494-3728.

Received: 25 January 2013; in revised form: 8 March 2013 / Accepted: 12 March 2013 / Published: 25 March 2013

\begin{abstract}
Declarations for sustainability in higher education are often seen as a set of guiding principles that aid institutions of higher learning to incorporate the concept of sustainability into their various institutional dimensions. As the Decade of Education for Sustainable Development draws to a close and in the shadow of the 20th anniversary of the Earth Summit in Rio de Janeiro, it seems appropriate to re-evaluate how these declarations have changed over the past two decades. In this study, we apply critical discourse analysis to examine how sustainability and the university are socio-politically constructed within these documents. Our analysis uncovers evidence of ideological assumptions and structures that are potentially misaligned with notions of sustainability often discussed in the Sustainability in Higher Education (SHE) literature. It is not the purpose of this study to provide a definitive reading of the documents, but rather to ply a novel critical lens to help elucidate how some taken-for-granted assumptions present in the declarations may work against their stated goals.
\end{abstract}

Keywords: critical discourse analysis; sustainability; higher education; declarations 


\section{Introduction}

The evolution of university declarations for sustainable development maps a series of benchmarks with respect to post-secondary institutions' commitment to incorporating principles of sustainability into their physical and philosophical dimensions. Many contend that as institutions that educate many of the future leaders of our society, universities bare a profound moral obligation to promote sustainability through their curricular, pedagogical and physical operations [1-4]. As microcosms of the greater society in which they find themselves embedded, universities ought to act as a testing ground for a variety of sustainable potentialities. Thus, the university is often conceptualized as a change agent from out of whom socially transformative notions of sustainability are meant to emerge [5]. Sustainability in Higher Education (SHE) declarations and charters are designed as guiding documents for aiding universities to incorporate the philosophies and tenets of sustainability into all functions of the university and, through becoming signatories, communicate a university's commitment to sustainable development (SD).

Though institutional transformation for sustainability is a laudable goal, the contested and protean nature of the concept of sustainability presents a significant challenge when using it as an organizing principle for change [6,7]. Singular- and consensus-based visions of sustainability, such as those born out of SHE declarations, risk muting important conceptual differences between conflicting or incompatible interpretations of the concept and may work to marginalize dissenting positions that are in tension with more dominant interpretations [8]. Therefore, while some proponents of SHE may envision sustainability as a platform from which to critique and reform the pre-existing institutional structures that drive socio-ecological crises [9], others contend that dominant constructions of sustainability are part of an ideological apparatus that seeks to (re)produce the very structures adherents to the former position we hope to critique. For those who engage in the latter discourse, the tacit commitment to anthropocentrism and ecological modernization inherent to mainstream conceptualizations of sustainability leaves neoliberal ideological assumptions about the nature of nature and the role of humans in the biosphere unquestioned and, as a result ensures the perpetuation of unsustainable socio-ecological arrangements [10,11]. It is not necessarily the purpose of this paper to comment on the validity of either position, but simply to demonstrate that different contestations will likely drive different meanings and usages and that sensitivity to certain forms of contestation may be consistently marginalized in the declarations.

Institutional change for sustainability is further complicated by the fact that the university system as a whole is in a period of transition as a result of the waning power of the nation state. This shift in the contemporary university is often framed in terms of the corporatization or neoliberalization of higher education (HE) [12-14]. In the Canadian context, lack of government funding has created the conditions for a shift away from traditional arrangements that tended to favour academic autonomy to institutional managerialism in decision-making processes, the adoption of performance indicators as measures of success and targeted funding in research as a means of driving innovation $[15,16]$. Moreover, the focus on education has shifted away from transformative or emancipatory conceptions toward more instrumentalist forms predicated on imparting the skills and knowledge required to be successful in a rapidly changing global economy [17]. Given that neoliberalist ideology has traditionally proven itself unsympathetic to transformative calls for global sustainability and that the 
authors of SHE declarations find themselves embedded in institutions that are arguably undergoing a process of neoliberalization; an examination of the assumptions embedded in the SHE declarations seems warranted.

While several studies have analyzed the content and themes of these SHE declarations as they've evolved over time $[2,18,19]$, there are no studies that we are aware of that examine the political assumptions embedded in the language of these declarations and how such assumptions may work to simultaneously produce and reproduce (from here on, written (re)produce) ideological structures that are potentially misaligned with socially transformative notions of sustainability.

Building on the work of Wright [19] and Lozano [18], we used critical discourse analysis (CDA) to develop a critique of SHE declarations spanning two decades, examining how these declarations (re)produce the notion of sustainability, the university and the nature of the current socio-ecological crisis.

\section{The CDA Approach}

Critical discourse analysis is well placed as an analytical tool for providing a novel and critical perspective on the underlying assumptions embedded in the language of SHE declarations. Rooted in critical social theory, CDA makes no claim to neutrality; in fact, it takes an explicit socio-political stance in order to gain deeper insight into how text is used in the (re)production of dominance and the hegemony inherent in notions of common sense and the status quo [20,21]. The primary site of analysis is text and talk, and the function of that analysis is to make visible the relationship between individuals, language, discourse and power. Central to this ontology is the idea that "Social agents are not free agents, they are socially constrained, but nor are their actions totally determined. Agents have their own "causal powers", which are not reducible to the causal powers of social structures and practices" where agents are dialectically engaged with the structures and practices, which are at once socially constituted and constitutive ([22], pp. 22).

CDA moves beyond content analysis of traditional reporting to demonstrate how strategic use of textual devices obfuscates the economic, political and cultural interests that permeate mainstream mass communicative events [23]. For CDA, news media, government communiqués and policy papers can be understood as specific genres that with their broad audience and pretence of neutrality, are a powerful means of manufacturing public perception and, ultimately, help to construct the conventions that society operates upon $[21,22,24]$. Declarations, such as university declarations for SD, can be understood as a specific textual genre whose purpose is, as Lozano et al. [18] describe: "to provide guidelines or frameworks for Higher Education Institutions to better embed sustainability into their system". Flyvberg argues that "power concerns itself with defining reality rather than discovering what reality "really" is [25]." Whether it is done wittingly or unwittingly, sustainability declarations employ specific structural, thematic, rhetorical and metaphoric elements that work to (re)produce a particular ideological stance.

SHE declarations, much like other policy statements, represent a consensus from the signatories or authoring agency, where difference tends to be minimized and, therefore, represents perhaps the simplest, most paired down visions of sustainability for the institutions. Thus, problematic assumptions and assertions situated in these texts may point to fundamental problematic themes in universities' construction of sustainability and their roles in working towards it generally. The presence of such 
assumptions is of particular interest, especially in light of how, through research and education, higher education is complicit in propagating and legitimizing many of the rationalizations and technologies that underpin much of the current crisis of unsustainability [1]. As previously stated, the purpose of this study is to explore how social agents use language in the SHE declarations to (re)produce specific dominant and ideologically-driven conceptualizations of sustainability and the university and how these intersect to frame not only the current socio-ecological crisis, but also the gambit of possible responses.

Though SHE declarations may not have the broad and immediate reach of the popular media, they nonetheless guide or frame what is possible insofar as sustainability is concerned at the university. If sustainability is constructed in a transformative, radical and profound way, it stands to reason that that vision of sustainability will begin to affect earnest change. Of course, the same would be true of any less altruistic goals or values embedded in the documents. Moreover, keeping in mind that as socially constrained agents within an institution that has itself been criticized for adopting neoliberal values, the potential exists for authors to be constrained in their ability to employ language to construct their interpretation of sustainability if they are forced to (consciously or unconsciously) operate within a neoliberal frame.

If the SHE documents are to be as effective and wide-reaching as they aim to be, some thoughtfulness into what values may be embedded in these documents seems quite fitting. Our primary concern is with how language and sites of power intersect and work to (re)produce dominance and inequality (or the opposite), since these texts are created by a particular and privileged group of people proposing to speak for a large group of people (both specific universities, the "university community" on a global scale and several specific countries or groups of countries). In other words, those whose social positions afford them privileged access to tools of mass communication are in such a position as to be able to have their social constructions of reality become the dominant interpretation, whereby, over time, they cease to be perceived as ideology and are incorporated into the discourses of civil society as either common sense or objective fact. It is the goal of this study to problematize the taken-for-granted assumptions embedded in the language of the declaration, so that future declarations may be constructed with a greater degree of reflexivity.

\section{Methodology}

The sample for this CDA focused on ten sustainability declarations spanning twenty years (Table 1). The specific declarations chosen for analysis were selected based on their presence in both Wright [19] and Lozano [18]. The intent was to build upon these analyses and to facilitate subsequent comparison across all three works. In her analysis, Wright [19] traces the content of explicit themes present in the documents and how they may or may not have evolved over time. Lozano et al [18] analyzed the documents for "complexity" and, paralleling Wright's work, how a more nuanced understanding of sustainability may have developed within the declarations over time. These ten declarations and charters both replicate themes from previous declarations, as well as introduce new concepts of their own, to varying degrees.

For the purpose of this analysis, four linguistic devices or "tools" widely applied by CDA [20-23,26] were used to draw out particular ideological positions embedded in the texts: 
(1) Intertextuality: The intertextuality of a text is the presence in it of aspects of other texts and, as a result, the presence of voices other than the authors. Thus, certain words, expressions and metaphors, which hold specific ideological meaning in other contexts, find their way into the particular text of concern. Divorced from their original context, these devices are argued to imbue the new text with meanings associated with the old [27].

(2) Modality: The modality of a sentence sets up the relationship between the author and the representation, in essence, what authors commit themselves to in terms of truth or necessity. Deontic modality is the modality of a statement concerned with necessity or obligation. Thus, employing words like "may" rather than "must" modalize a sentence in such a way as to place it between a categorical assertion and a denial, making the authors position either weak or ambiguous ([22], pp. 22). CDA is interested in identifying shifts in deontic modality.

(3) Nominalization: A type of grammatical metaphor that represents processes as entities by transforming clauses into a type of noun. For example, "industrial society degrades the environment" can be worded as "environmental degradation", where the active agent is removed from the sentence. In text, this is argued to naturalize certain relationships, in this case, framing environmental degradation as a passive or inevitable process divorced from any historical agent $[24,26]$.

(4) Structure and Framing: Structure here is understood to be how hypotactically related clauses imply a superordinate or subordinate relationship between statements and how the nature of these relationships can frame subsequent statements within a complex sentence ([22], pp. 92-94). Framing is similar to structure, but concerns how a statement or group of statements is placed in a superordinate position in a text, where it is content can be used to infuse subsequent statements with a particular meaning. (This is of particular interest in the SHE declarations, where superordinate and subordinate relationships between statements advanced in the preamble help to frame all the recommendations that follow) [20,24].

Table 1. List of Sustainability in Higher Education (SHE) declarations analyzed in this study.

\begin{tabular}{|c|l|}
\hline Year & \multicolumn{1}{|c|}{ Declaration } \\
\hline 1990 & The Talloires Declaration (ULSF, 1990) \\
\hline 1991 & $\begin{array}{l}\text { The Halifax Declaration (See Lester Pearson institute for } \\
\text { international development, 1992) }\end{array}$ \\
\hline 1993 & The Kyoto Declarations (UNESCO, 1993) \\
\hline 1993 & The Swansea Declaration (UNESCO, 1993) \\
\hline 1994 & The CRE Copernicus Charter (CRE-Copernicus, 1994) \\
\hline 1997 & Thessaloniki Declaration (UNESCO, 1997) \\
\hline 2001 & Luneburg Declaration (UNESCO, 2001) \\
\hline 2005 & The Graz Declaration (Oikos, Copernicus, TUG, 2005) \\
\hline 2009 & The Bonn Declaration (UNESCO, 2009) \\
\hline 2009 & The Turin Declaration (G8, 2009) \\
\hline
\end{tabular}

The process of analysis for this study was influenced by Porter, who analyzed health declarations and provided a practical set of guidelines for analyzing a similar genre of text [26]. Each declaration was read multiple times, employing each of the four tools outlined above as an analytic lens. It is 
important to note that it is the identification of the presence of these linguistic devices as they are employed by the author(s) of the declarations that form our initial substantive analysis. Therefore, what we mean by "tool" is that we identify instances of intertextualization or nominalization, for example, in the texts. Subsequent analysis links these together as a whole, attempting to highlight how these linguistic devices are employed to (re)produce dominant or repressive ideologies.

Much like a thematic analysis of text, where the researcher initially creates a substantive codebook (essentially, just a reporting of what was said) before developing a set of theoretical codes that lead to theory building [28,29], initial reading of the declarations was conducted to locate substantive instances of the linguistic devices outlined above. These instances were highlighted with notations attached outlining the specific device employed in the text, as well as some cursory notes about how they may represent ideological (re)production. Subsequent analysis concerned itself primarily with the previously identified linguistic devices and the relationships these created within the text and to ideological structures outside of the texts. From here, two broad thematic categories were identified as sites of ideological reproduction, which were potentially maligned with transformative conceptualizations of sustainability, those being: problematic construction and reproduction of the university; and problematic constructions and reproductions of sustainability and the sustainability issue, respectively.

In order to organize observations, we created a spreadsheet that noted the declaration, citation, the location of citation within the document, tools identified and implications or themes that emerged. A separate sheet was created for both categories, and upon completion, we used a critical eye to remove redundancies to simplify the tables for the reader. The spreadsheet allowed easy tracking of emergence, ideological (re)production and disappearance or omission of certain themes. Since these declarations are largely built off each other and sometimes almost identical textually, it is noteworthy to identify where differences and commonalities can be found.

\section{Results and Discussion}

The following section shows the results of our analysis. In this, we review two emergent/established themes that we feel bear discussion. It is not our intent to underscore the importance of these documents for sustainability in higher education; nevertheless, there exists potentially problematic language employed in the construction of conceptualizations of both the university and sustainability, which we argue work to (re)produce an inherently unsustainable status quo.

\subsection{Construction and Reproduction of the University}

Analysis of the declarations revealed a consistent conceptualization, on the part of the authors, of the university as a site of free and open inquiry, which bears a responsibility to society to develop novel ways of doing and being, which is static, for the most part, across all declarations. For example, the Talloires Declaration states:

Universities have a major role in the education, research, policy formation and information exchange necessary to make these goals possible. Thus, university leaders must initiate and 
support mobilization of internal and external resources so that their institutions respond to this urgent challenge [30].

In addition, the Turin Declaration demonstrates:

...the Presidents attending the 2009 University Summit acknowledge the important role that education and research play in informing, promoting and implementing sustainable and responsible development [31].

This conceptualization of the university is ubiquitous across all declarations and echoes perceptions of the role of the university vis-à-vis sustainability in much of the SHE literature [9,32].

Equally ubiquitous and directly related is the omission of any mention of culpability on the part of universities for how knowledge generated within their walls has contributed to the current socio-ecological crisis. All declarations readily construct the university as the solver of societies "problems", and to an extent, it can be and is, but discussing the obverse of this issue without admitting its reverse, we argue, displays a lack of reflexivity on the part of the declarations, which may imply a lack of self-reflection on the part of universities. Even if the ultimate role of SHE declarations is developing or highlighting potential avenues through which the principles of sustainability can be incorporated into the functioning of the institution, not demonstrating an understanding of how the institution's actions have contributed to "unsustainability" may run the risk of new directions falling into old traps. This is a potentially problematic thread that binds all the declarations together and is seemingly static over time. There is no obvious political tack at play in this particular (re)production of the university; rather, we take this as evidence of a deeply held, somewhat traditional view of the university as an engaged social agent that is an artifact of the institutional upheavals (centered in American Universities) of the 1960s and 70s [33]: Statements, such as this in the Copernicus Charter...

It is consequently their duty to propagate environmental literacy and to promote the practice of environmental ethics in society... [34].

...where it is asserted that the university must engage the public sphere is present in most all declaration. In fact, it increases dramatically in frequency (e.g., Talloires Declaration refers to this in separate sentences, while the Bonn Declaration uses this as a central theme and, thus, completely saturated) over the twenty year span of the sample, alluding to a strong, socially progressive politic emerging out of the declarations. It is not our intent to criticize universities seeking to become more socially relevant; on the contrary, this should be applauded. Nonetheless, failing to realize or admit culpability associated with participating and supporting a system that has proven itself to be ecologically and socially disruptive on a global scale speaks to a hubris, which may inhibit the institution from engaging in the sort of re-examination of its current pedagogical and ethical structures that may be more conducive to a socially transformative notion of sustainability.

Although multiple common themes present in the declarations give the appearance of continuity and, at times, a progressive evolution of how the university is perceived vis-à-vis its role in society, another more subtle evolution exists within the declarations as a collection of writing that sees an increase in the presence of neoliberal or "Free Market" discourses over time. This is noteworthy, because, as a structure and framing device, neoliberal language implies a very specific understanding 
of what sustainability and universities ought to be: instruments for economic growth. Though some criticism may be advanced to how early declarations construct "the University" and its role in promoting sustainability, there is little textual evidence to support the promulgation of any specific political ideology. In fact, little in the way of discernible neoliberal discourse is to be found until the Thessaloniki Declarations:

"The reorientation of education as a whole called for in chapter 36 of Agenda 21 must involve not only the education community, but also governments and financial institutions and all other actors [35]."

Throughout all proceeding declarations, relationships between the State and universities have been discussed. This is the first instance where financial institutions have been explicitly given a role to play into the "reorientation of education". Moreover, they are given a privileged position, since they are named, while other constituencies, such as the citizenry, NGOs, etc. are relegated to being lumped into "all other actors". We contend that giving financial institutions a privileged position in the reorientation of $\mathrm{HE}$ without justification demonstrates linkages between $\mathrm{HE}$ and the financial institutions that at the time of the creation of the declaration were exceedingly rare and potentially illustrate the emergence of neoliberal values. Marginson and Considine [36] make a similar claim in their critique of the participation of a Tokyo-based transnational financial institution in the creation of the West Report (an Australian report on HE financing), which called for the explicit adoption of neoliberal management strategies. Though this is but one example, given the explicit adherence to neoliberalism on the part of financial institutions, it stands to reason that giving them a privileged position with respect to the reorientation of HE for sustainability marks a shift in the tone, tenor and ideological thrust of the declarations. How universities are meant to effectively critique financial institutions (who arguably are primary actors in the current socio-ecological crisis) if they are being "reoriented" by these same institutions is a difficult question indeed, especially if the dominant ideology of financial institutions today is free market fundamentalism born out of a neoliberal system ([37], pp. 2-3). This is the first instance within the declarations where what can be considered neoliberal discourse is being given a prominent and privileged position within the text. The emergence of a neoliberal discourse of HE can be seen as creating a discursive tension between traditional conceptualizations of the university as "free and independent" with a more corporatized vision of the institution.

In drawing from Fairclough's notion of genres of text and how specific genres are employed to specific ends, we begin to uncover what is occurring in these texts. The genres of policy papers, of which the declarations most closely resemble, bare the central feature of diminishing difference ([20]; [22], pp. 100-101). As a consensus-based piece of writing, important and unresolved conflicts tend to be muted and presented to the reader in the form of a unified and single voice, creating the illusion of a common vision; for example, the Luneburg Declaration, where a traditional view of the university is given:

"It (higher education) has a special responsibility to conduct the scholarship and scientific research necessary to generate the new knowledge needed and train the leaders and teachers of tomorrow, as well as communicate this knowledge to decision makers and the public at large [38]." 
If one can forgive the post-positivist slant in assuming "one" knowledge or that the authors seem to conflate knowledge and information, the central thrust of this statement speaks to an institution engaged in the public sphere by forming and disseminating a variety of ideas that will help to move society in a more sustainable direction. Thus, in a traditional or even liberal arts conceptualization, we see the university as an independent pillar of society helping to drive social change. This is perhaps even better exemplified in the following quote, where education at the university is discussed in terms of education of the whole being, which aligns itself with a liberal vision of the institutions as a site for free and critical learning, where knowledge is viewed as emancipatory (the Luneburg Declaration):

"The ultimate goal of education for sustainable development is to impart the knowledge, values, attitudes and skills needed to empower people to bring about the changes required to achieve sustainability [38]."

However, the preceding paragraph in a seemingly benign statement of broad purpose for the university proposes:

"Higher education has a catalyst role vis-à-vis education for sustainable development and the building of a Learning Society [38]."

Though the concepts of a Learning Society and lifelong learning by association do hold promise for socio-ecological resilience, plying them uncritically is problematic in that intertextually speaking they can be understood as specifically neoliberal forms of a state of reason that have emerged largely as a result and effect of the flexibility required to meet the demands of increasingly complex and ever-expanding economies of scale. As Olssen argues, drawing on Foucault's concept of governmentality, lifelong learning as an educational ethic can be understood as a technology of control situated in a discourse for the "flexible preparation of global subjects" [39]. Furthermore, the notion of a learning society works to develop the discourse of the individualization of the responsibility for education, which is now framed as education for the participation in an ever-changing global marketplace, all the while absolving any responsibility on the part of the State for the provision of education. Moreover, this translates into an erosion of workers' rights, where adaptability becomes a key component of human capital and is the responsibility of the individual [40]. In other words, the individual becomes an entrepreneur of the self, subject to perpetual economic tribunal, which constitutes the dissolution of separation between the social and the economic spheres [40]. Within this example taken from the Luneburg Declaration, the brief statement of purpose linking the university to the Learning Society can be used to better contextualize the statements that follow (with structure and framing being the obvious CDA tool). Without the 'Learning Society' framing device, education and the university are potentially constructed in an emancipatory sense (note the use of the word "empower"). Through the presence of this framing device, we argue, education is recast along instrumentalist lines constructing it as the preparation of flexible subjects by imparting them with the skills required to be individually successful in an ever-changing market economy, where success also means dealing with the inevitable and concomitant socio-ecological crisis. This muted juxtaposition of conflicting positions, whereby differences between instrumentalist and emancipatory forms of education are diminished, is reproduced throughout all declarations (to varying degrees) from Thessaloniki [35] onward and works to sustain the illusion that the university can at once function as a 
site of free and open inquiry, while embodying the values of a neoliberal market economy without significant compromise on the part of one of the positions. In fact, even more jarring is its presence in the Turin Declaration, albeit through the use of different language:

"Sustainability cannot be achieved by merely engaging natural sciences, but must also engage life sciences, social sciences and humanities [31]."

This of course presents a somewhat enlightened view of the necessity of sustainability being understood broadly, beyond mere technical definitions, but then tied to the following:

"All students should be exposed to the issues connected with sustainable development and encouraged to be involved in the creation of a sustainable and responsible society in the spirit of global citizenship [31].”

As with "Lifelong Learning", "Global Citizenship" may also be understood as yet another form of institutional reason that is embedded in a neoliberal web of significance [41]. Structurally speaking, the concept of global citizenship works to further naturalize globalization as an ideology, as well as the current uneven terms of global trade. The presence of this form of neoliberal rhetoric, albeit significantly diluted, within the declarations points to the presence of ideological structures, which have traditionally been less than sympathetic to calls for transformative notions of sustainability. Whether a more corporatized institution can still be a site of free and open inquiry is far from decided. However, we ally ourselves with $[24,37,39,42]$ in arguing that this claim is dubious at best. This has serious ramification, as we shall see, for how sustainability is conceptualized within universities and, as a result, within these declarations.

\subsection{Construction and Reproduction Sustainability and Sustainability Issues}

Perhaps the most striking finding to be drawn out of our analyses is the consistent naturalization of the processes that lead to issues of global sustainability (in this instance, ecological degradation and poverty) through nominalized statements, as found in the Talloires Declaration...

We, the presidents, rectors, and vice chancellors of universities from all regions of the world are deeply concerned about the unprecedented scale and speed of environmental pollution and degradation and the depletion of natural resources.

Local, regional, and global air and water pollution; accumulation and distribution of toxic wastes; destruction and depletion of forests... [30]

....as well as in the COPERNICUS Charter:

Man's exploitation of the biosphere is now threatening its very existence and balance [34].

Where poverty is concerned, the Bonn Declaration opens with the statement:

Despite unprecedented economic growth in the $20^{\text {th }}$ century, persistent poverty and inequality still affect too many people [43].

and:

Unsustainable production and consumption patterns are creating ecological impacts... [43]. 
By framing these issues as naturally occurring phenomena, the authors obfuscate the fact that these are indeed historically embedded phenomena that are the result of very specific socio-economic relations promulgated by historically embedded agents who actively seek to (re)produce these relations. The danger, in particular, with the naturalization of ecological degradation and poverty is that it removes agency and, thus, invisibilizes the institutional structures that perpetuate them, thereby making it virtually impossible to address the core of the problems. Structurally speaking, for example, the quotation drawn from the Bonn Declaration [43], by employing the word "despite", draws a link between poverty and economic growth that implies the latter as a solution to the former. This betrays a very specific neoliberal worldview about economic growth as an unequivocal social good ([37], pp. 2-3), denying that such growth is often predicated upon the uneven terms of global wealth distribution and the perpetuation of poverty as a result $[44,45]$. Nominalizing ecological degradation and poverty and the resultant disavowal of their historicity, as we have argued, invisibilizes essential dimensions of the problems. Aside from leaving dominant social structure unchallenged, they also enable the declarations to frame the majority of their responses in techno-managerial terms.

Framing responses in techno-managerial terms implies a necessary framing of sustainability along similar lines. This is perhaps best evidenced by consistent reference throughout the majority of the declarations to the Brundtland Commission's definition of sustainable development. This occurs as late as the Turin Declaration [31], where a direct quote from the Brundtland Report (1987) is used as an intertextual/framing device by its placement in a prominent position prior to the actual body of text. Although the Brundtland Report is no doubt an important part of the history of sustainability, the concept has evolved considerably since its original publication [46]. Evoking the Brundtland Commission as an intertextual/framing device speaks to a very specific, very narrow conceptualization of sustainability that has been problematized by some [47] for being predominantly techno-centered in nature and for (re)producing mainstream ideological contradictions, such as the possibility of ecological conservation in a world of perpetual economic growth. Thus, we argue that the presence of the Brundtland discourse works to infuse the declarations in which it is present-e.g., Copernicus, [34]; and Turin, [31] — with a particularly technical vision of sustainability that does not call into question the mainstream socio-economic structures that contribute significantly to the current socio-ecological crises.

The issue with techno-managerial- and expert-driven solutions is that they are inherently technocratic rather than democratic, effectively removing agency and power from civil society. Though the Brundtland discourse is by and large absent from the other declarations-Talloires [30]; Thessaloniki [35]; Luneburg [38]; and Bonn [43] — there is still a predominance of techno-managerial language in their discussion of solutions. We can see how the declarations focus on techno-managerial solutions through highlighting the "best research" and "latest technology" [38] with little to no discussion of the socio-economic relations that produce the problems. Even progressive language, such as in the Thessaloniki Declaration [35], can be viewed as inherently problematic in this light...

[...] rapid and radical change of behaviours and lifestyles, including changing consumption and production patterns. For this, appropriate education and public awareness should be recognized as one of the pillars of sustainability together with legislation, economy and technology [35]

as well as in the Bonn Declaration:

We have the knowledge, technology and skills available to turn the situation around [43]. 
Where in the Thessaloniki Declaration the three of the central pillars are explicitly the realm of techno-managerialists and the fourth, while admitting the necessity of social change, frames this in terms of individual action and responsibility. Conversely, even though the Bonn Declaration does admit the need for cultural change without explicitly framing this in individual terms, suggesting that the root of the current socio-ecological crisis are values and lifestyle choices without critiquing the social structures that create and reinforce those very values (for their benefit), presents culture as ahistorical and the product of some inevitable "human nature". Presenting the individual as a basic, ahistorical social unit further works to (re)produce an ideological position situated in a neoliberal rhetoric of individuals as free from socio-economic constraints and as the sole site of social responsibility [37]. This is not to say that behavioural change is not a necessity for a sustainable society; only as presented here, the way in which it is framed in these examples suggests they are "natural" or inevitable, when in reality, they are the result of very specific and historically embedded, processes and practices. We take this as preliminary evidence of the presence of an emerging neoliberal economic discourse; a discourse whose presence may work to frame sustainability in highly techno-centric terms, where the underlying structures that are linked to global unsustainability remain unchallenged.

\section{Conclusions}

Both Wright [19] and Lozano et al. [18] admit and discuss the presence of an evolution across the declarations. Our findings align on the issue of prominent themes of moral obligation and the importance of engaging with the public sphere. In terms of the central theses concerning evolution across these documents, Wright finds that though a great deal of continuity exists, the nuance with which they construct the notion of sustainability and the role of the university deepens potentially as a result of the declarations building off one another. In addition, Wright notes that there is evidence to suggest that the declarations, or at the least their authors, demonstrate a greater awareness of what roles such texts can play in helping to implement principles of sustainability in the institution. Lozano et al. build on Wright, echoing many of her assertions and adding several themes they found to be important. In their analysis, they find that the date on which a declaration was created relative to the others has no relationship to progression in complexity and size over time. They do however assert that individual institutions tend to significantly lag behind the goals and recommendations set by the declarations.

Our application of CDA reveals that although many themes remain consistent through time, there is evidence of a marked ideological shift between the Copernicus Declaration and the Thessaloniki Declaration. This shift is evidenced by the presence of language and textual devices in the writing of the declarations that in the previous section we have argued work to (re)produce neoliberal market ideology. While an in-depth discussion of the socio-political conditions at work between 1993 and 1997, which may lead to such a shift in the ideological slant of the declarations, is beyond the scope of this paper, it is interesting to note that during this time frame, reports, such as the Commonwealth governments review on higher education financing [48], and policy were being produced in rarely before seen collaboration with financial institutions ([36], pp. 42-45). In the specific case of the West Review, Global Alliance Limited (GAL), a Tokyo-based transnational financial institution, played a 
key role in informing many of the policy prescriptions that found their way into the review, explicitly calling for Australian universities to adopt a far more neoliberal market-based approach to their current funding structures [48]. With discussions such as these occurring with greater and greater frequency throughout the 1990s [36,49], the emergence of neoliberal discourses in the language of the sustainability declarations seems inevitable. This is not to say that there is a linear progression of "intensity" with respect to the presence of such discourses, only that after a certain point in time, they seem to become embedded in the manner in which the declarations are constructed and, as a result, may be embedded in the way the texts are (re)producing a vision of the university and sustainability. This points to what ourselves and many others have argued is a trend of neoliberalization or marketization of the institution that is perceived as eroding traditional values of excellence in free and open inquiry, as well as education $[33,49,50]$.

We respectfully disagree with Lozano et al. [18], who state that universities are slow to change and are still embedded in Cartesian and Newtonian modes of knowledge creation, as our research and that of others provide evidence that universities are taking significant steps away from the 1traditional structure and role in society [33,36,49]. As knowledge production and funding structures change, it is arguably reliance on a traditionalist view of the academy that will help ward off ideologies that limit academic freedom as knowledge becomes produced, necessarily so, more in the context of its application (which is arguably the root of sustainability sciences). Rather than chastising the academy for its slowness to change, we applaud it, since rapid institutional change presents risks of being maladaptive [51,52].

As we have mentioned above, it is not the purpose of this paper to provide a definitive and final reading of SHE declarations. Rather, our intent is to add to the growing body of literature that seeks to provide a more critical assessment of sustainability in higher education. Our concern is with the spontaneous emergence of disciplinary structures with respect to thought around sustainability and how these structures may be functionally transparent to people embedded in the field. We feel that the persistence of themes in the declarations that we have argued are problematic may be indicative of the emergence of disciplinary thinking around sustainability and may work to limit a vision of what a sustainable university can look like. On a practical level, our intent with this work is to hopefully demonstrate the need for a more critical and reflexive approach in creating SHE declarations and to be sensitive to the sort of ideological (re)production that plague politically contested concepts, like sustainability. Language and discourse are powerful ways of reproducing ideology and maintaining hegemonic social relations; relations that in a contemporary socio-economic context, are not necessarily aligned with transformative visions of sustainability. Since social agents are partially socially constituted, reflexivity is exceedingly important in any work that seeks to promote social change if we do not want to unwittingly (re)produce the very ideologies and social structures we are seeking to critique or dismantle.

Finally, although the themes of sustainability in the declarations appear static over time, set against the emergence of a neoliberal ideology as a framing device, we argue that they are anything but. In other terms, the words are the same, but the meaning has changed. Instead of seeking to use the principles outlined in the declarations to sew "a golden thread" through the university, we humbly suggest using the principles to develop a number of critical sustainabilities in constant tension. Therefore, rather than trying to craft a singular or consensus vision of sustainability at the university 
(which is likely a chimera), contestation around the concept should be seen as an opportunity to develop a plurality of divergent positions in interaction with one another from out of which the potential for premise reflection and deep social learning may occur. The challenge is finding a way to institutionalize such tensions under the umbrella of individual universities to promote the sort of communication between divergent perspectives required if a notion of critical sustainabilities is to foster social learning. In addition, the lack of reflexivity demonstrated within the declarations, by omitting discussion or mention of the role that universities have played in the current crisis of sustainability, must be addressed. Imbuing the university with the principles of sustainability should begin with an examination of how it has traditionally functioned in society; an examination that uses critical notions of sustainability (or sustainabilities) as a platform for internal critique of taken-for-granted sociopolitical and socioeconomic institutional structures that do not align with transformative visions of sustainability.

\section{Conflict of Interest}

The authors declare no conflict of interest.

\section{References and Notes}

1. Orr, D.W. Ecological Literacy: Education and the Transition to a Postmodern World; State University of New York Press: Albany, NY, USA, 1992.

2. Clugston, R.; Calder, W. Critical dimensions of sustainability in higher education. In Sustainability and University Life; Leal Filho, W., Ed.; Peter Lang: Berlin, Germany, 1999; pp. 31-46.

3. Wright, T.S.A. Definitions and frameworks for environmental sustainability in higher education. J. Clean. Prod. 2002, 3, 203-220.

4. Velazquez, L.; Munguia, N.; Platt, A.; Taddei, J. Sustainable university: What can be the matter? J. Clean. Prod. 2006, 14, 810-819.

5. Wals, A.E.J. Learning Our Way to Sustainability. J. Edu. Sust. Dev. 2011, 5, 177-186.

6. Cotton, D.R.E.; Warren, M.F.; Maiboroda, O.; Bailey, I. Sustainable development, higher education and pedagogy: A study of lecturers' beliefs and attitudes. Env. Educ. Res. 2007, 13, 579-597.

7. Thomas, I. Sustainability in tertiary curricula: What is stopping it happening? IJSHE. 2004, 5, 33-47.

8. Wals, A.E.J. Learning Our Way to Sustainability. J. Edu. Sust. Dev. 2011, 5, 177-186.

9. Cortese, A.D. The critical role of higher education in creating a sustainable future. Plann. High. Educ. 2003, 31, 15-22.

10. González-Gaudiano, E. Education for Sustainable Development: Configurations and meaning. Policy Future Educ. 2005, 3, 243-250.

11. Kopnina, H. Education for sustainable development (ESD): The turn away from "environment" in environmental education. Env. Educ. Res. 2012, 18, 699-717.

12. Giroux, H.A. Neoliberalism, Corporate culture, And the promise of higher education: The university as a democratic public sphere. Harvard Educ. Rev. 2002, 72, 425-463. 
13. Jickling, B.; Wals, A.E.J. Globalization and environmental education: Looking beyond sustainable development. J. Curriculum Stud. 2008, 40, 1-21.

14. Noble, D.F. Digital diploma mills : The automation of higher education. Sci. Cult. 1998, 7, 355-368.

15. Metcalfe, A.S. Revisiting academic capitalism in canada : No longer the exception. J. High. Educ. 2010, 81, 489-514.

16. Newsome, J.; Polster, C. Reclaiming our center: Toward a robust defense of academic autonomy. In The Exchange University: Corporatization of Academic Culture; Fisher, D., Chan, A.S., Eds.; UBC Press: Vancouver, BC, Canada, 2008; pp. 125-146.

17. Wals, A.; Jickling, B. 'Sustainability' in Higher Education: From Doublethink and Newspeak to Critical Thinking and Meaningful Learning. IJSHE 2002, 3, 221-232.

18. Lozano, R.; Lukman, R.; Lozano, F.J.; Huisingh, D.; Lambrechts, W. Declarations for sustainability in higher education: Becoming better leaders, through addressing the university system. J. Clean. Prod. 2011, in press.

19. Wright, T. The evolution of sustainability declarations in higher education. In Higher Education and the Challenge of Sustainability; Corcoran, P.B., Wals, A.E., Eds.; Kluwer Academic Publishers: Dordrecht, The Netherlands, 2004; pp. 7-19.

20. Fairclough, N. Discourse and Social Change; Polity: Cambridge, UK, 1992.

21. Van Dijk, T.A. Discourse \& society. Discourse Soc. 1993, 4, 249-283.

22. Fairclough, N. Analyzing Discourse: Textual Analysis for Social Research; Routledge: London, UK, 2003; p. 22.

23. Blommaert, J.; Bulcaen, C. Critical discourse analysis. Ann. Rev. Anthropol. 2000, 29, 447-466.

24. Herman, E.S.; Chomsky, N. Manufacturing Consent: The Political Economy of the Mass Media; Pantheon Books: New York, NY, USA, 2002.

25. Flyvbjerg, B. Rationality and Power: Democracy in Practice; University of Chicago Press: Chicago, IL, USA, 1998.

26. Porter, C. Ottawa to Bangkok: Changing health promotion discourse. Health Promot. Int. 2007, 22, 72-79.

27. Fairclough, N. Intertextuality in Critical Discourse Analysis. Ling. Edu. 1992, 4, 269-293.

28. Charmaz, K. Constructing Grounded Theory: A Practical Guide Through Qualitative Analysis; Sage Publications: London, UK, 2006.

29. Lincoln, Y.S.; Guba, E.G. Naturalistic Inquiry; Sage Publications: Oakland, CA, USA, 1985.

30. University Leaders for a Sustainable Future. Talloires Declaration; ULSF: Washington, DC, USA, 1990.

31. University Summit Turino Declaration on Education and Research for Sustainable and Responsible Development. Turin Declaration; G8 University Summit: Turino, Italy, 2009.

32. Wright, T. University presidents' conceptualizations of sustainability in higher education. IJSHE 2010, 11, 61-73.

33. Delanty, G. Challenging Knowledge: The University in the Knowledge Society; Society for Research into Higher Education \& Open University Press: Buckingham, UK, 2001.

34. Association of European Universities (CRE). COPERNICUS-The University Charter for Sustainable Development; CRE-Copernicus Secrateriate: Geneva, Switzerland, 1994. 
35. United Nations Education. Science and Cultural Organization (UNESCO); Thessaloniki Declaration: Thessaloniki, Greece, 1997.

36. Marginson, S.; Considine, M. The Enterprise University: POWER, Governance, and Reinvention in Australia; Cambridge University Press: Cambridge, UK, 2000; pp. 42-45.

37. Harvey, D. A Brief History of Neoliberalism; Oxford University Press: Oxford, UK, 2005; pp. 2-3.

38. United Nations Education, Science and Cultural Organization (UNESCO). Lüneburg Declaration. International COPERNICUS Conference "Higher Education for Sustainability-Towards the World Summit on Sustainable Development (Rio+10), Lüneburg, Germany, 4 October 2001.

39. Olssen, M. Understanding the mechanisms of neoliberal control: Lifelong learning, Flexibility and knowledge capitalism. Intern. J. Lifelong Edu. 2006, 25, 213-230.

40. Simons, M.; Masschelein, J. The learning society and governmentality. Educ. Phil. Theo. 2006, 38, 417-430.

41. Andreotti, V. Soft versus critical global citizenship education. Policy Prac. Dev. Educ. Rev. $2006,3$. Available online: www.developmenteducation.com/issue3-focus4/ (accessed on 10 December 2011).

42. Askehave, I. The impact of marketization on higher education genres - The international student prospectus as a case in point. Discourse Stud. 2007, 9, 723-742.

43. United Nations Education, Science and Cultural Organization (UNESCO). The Bonn Declaration; UNESCO World Conference on Education for Sustainable Development: Bonn, Germany, 2009.

44. Fonseca de Andrade, D. Challenging the Focus of ESD: A Southern Perspective of ESD Guidelines. J. Educ. Sust. Dev. 2011, 5, 141-146.

45. Hornborg, A. Zero-Sum World. Int. J. Comp. Sociol. 2009, 50, 3-4, 237-262.

46. Sneddon, C.; Howarth, R.B.; Norgaard, R.B. Sustainable development in a post-Brundtland world. Ecol. Econ. 2006, 57, 253-268.

47. Lélé, S. Sustainable development: A critical review. World Dev. 1991, 19, 607-621.

48. The West Committee. Learning for life: Review of Higher Education Financing a Policy (West Review); AGPS: Sydney, Australia, 1998.

49. Metcalfe, A.S. Revisiting Academic Capitalism in Canada: No longer the exception. J. High. Educ. 2010, 81, 489-514.

50. Etzkowitz, H. The evolution of the entrepreneurial university. Int. J. Technol. Glob. 2004, 1, 64-77.

51. Scott, W.; Gough, S. Universities and sustainable development: The necessity for barriers to change. Policy Prac. High. Educ. 2007, 11, 107-115.

52. Sherren, K. Silos, Students and Centralizing Forces: The Institutional Climate Affecting Innovations for Sustainability in the Tertiary Sector. Proceeding for the Australian Association for Higher Education, Adelaide, Australia, 30 November 2006.

(C) 2013 by the authors; licensee MDPI, Basel, Switzerland. This article is an open access article distributed under the terms and conditions of the Creative Commons Attribution license (http://creativecommons.org/licenses/by/3.0/). 